\title{
The Activity of Ptolemy II's Fleet in the Aegean Sea
}

\author{
Tomasz Grabowski \\ iD http:/orcid.org/0000-0002-2515-6920 \\ Jagiellonian University in Kraków
}

\begin{abstract}
Ptolemy I, the founder of the Lagid dynasty, heavily invested in the navy and thus established the Ptolemies as a formidable sea power, his work continued by his successor Ptolemy II Philadelphus, who employed his fleet to pressure lesser powers of the Mediterranean. The following article examines the activity of Ptolemy II's fleet in the Aegean Sea. At the end of the 270s, Ptolemy II sent a naval expedition to the Black Sea; the operation helped him establish a political relationship with Byzantion and demonstrated that maintaining a naval presence on foreign waters could influence other rulers to favor the Ptolemies. The Ptolemaic fleet under Ptolemy II Philadelphus operated in the Aegean during two major international conflicts, the Chremonidean War and the Second Syrian War. In this article I argue that the surviving evidence on the Chremonidean War indicates that Ptolemy II's aim was not to subdue Greece or even Macedonia but to maintain the Ptolemaic hold over the Aegean with Egypt's relatively small naval force under Patroclus. In turn, the outcome of the Second Syrian War led to a considerable weakening of the Lagids' position in the Aegean. Ptolemy II adroitly cultivated international relations through diplomacy, propaganda, international euergetism and spreading his dynastic cult; sending the Ptolemaic fleet to patrol foreign seas constituted one crucial instrument Philadelphus could employ to shift the Mediterranean balance of power in his favor.
\end{abstract}

Keywords: Ptolemy II, fleet, Aegean Sea, Chremonidean War, Second Syrian War.

The Lagids' naval power began as a personal ambition of the dynasty's founder, Ptolemy I, who during the Wars of the Diadochi consistently (and successfully) endeavored to strengthen his position in the Mediterranean Sea and achieve supremacy at sea. The Lagids' control over the Mediterranean began after the battle of Ipsus in 301. ${ }^{1}$ Ptolemy

1 All dates in the paper are BC. The present paper was completed thanks to the financial support from the National Science Centre (grant: UMO-2012/07/B/HS3/03455). This is a revised version of the text previously published in Polish, "Działania floty Ptolemeusza II na Morzu Egejskim," in: S. Sprawski (ed.), Wojna i wojskowość w świecie starożytnym, Kraków 2015, 71-93. 
captured Cyprus (the perfect naval base for the eastern Mediterranean), Tyre and Sidon (ports from which he could control the southern coast of Syria), and he subjugated the League of the Islanders that united the Cycladic poleis. Debatably, during this period the Ptolemies might have also gained important footholds on the coast of Asia Minor, although the chronology of Ptolemaic seaboard acquisitions in Asia Minor remains uncertain. $^{2}$

Ptolemy I's successor, Ptolemy II Philadelphus, continued his predecessor's naval policy and employed his fleet to influence foreign powers, sending ships across and beyond the Mediterranean, out to the Red Sea and up the Nile. Situated at the crossroads of Asia and Africa, the Lagid Empire, a maritime-facing country by virtue of its location, had to master the surrounding seas to ensure its survival. According to a well-known account in Athenaeus' Deipnosophistae, Ptolemy II's fleet outnumbered fleets of all other contemporary powers. Philadelphus reportedly commanded two 'thirties,' one 'twenty,' four 'thirteens,', two 'twelves,' fourteen 'elevens,' thirty 'nines,' thirty-seven 'sevens,' five 'sixes,' seventeen 'fives,' and - according to Callixeinus - twice as many smaller ships, from 'fours' to light warships called trieremiolia. In total, the Egyptian king reportedly had over three hundred warships, with his auxiliary naval force also including - according to this account - 4,000 other ships sent by him to allied cities and territories under his control. The account appears reliable in regard to the number of larger ships, ${ }^{3}$ some of numbers confirmed by epigraphic and papyrus sources. ${ }^{4}$ Athenaeus' passage does not specify the period of Ptolemy II's reign it refers to $;{ }^{5}$ nonetheless, the sheer size of the fleet at Philadelphus' disposal must have dwarfed all other navies. A large naval force kept the empire safe against foreign incursions and maintained the dynasty's position at sea, but it put a strain on Philadelphus' finances, with funds siphoned off to construction, upkeep (workmanship and material), naval base maintenance and sailors' remuneration. Therefore, we could say that the fleet not only maintained the Lagids' maritime empire but also demanded its existence, since operational costs incurred by the

2 Cf. Meadows 2006; Meadows 2012; Meuss 2014, 303-304.

3 Athen. 5.203d. Athenaeus does not quote his source, with the scholarly consensus identifying it as an excerpt from the work of Callixeinus of Rhodes, with ample evidence supporting this identification. First, the analysed passus forms a part of Athenaeus' reflections on the remarkable contemporary breakthroughs in shipbuilding, such as Ptolemy IV Philopator's tessarakonteres and thalamegos, with the author of the Deipnosophistae directly referring to Callixeinus' text while discussing Philopator's ships (Athen. 5.203f-208e). Second, the discussed fragment about Ptolemy II's fleet follows a description of the famous pompe organised in Alexandria by its ruler, also drawn from Callixeinus' account. Finally, the context in which Callixeinus' name appears in the text (Athen. 5.203e), between the passus on Philadelphus' fleet and the one on other exceptionally large or luxurious marvels of the shipbuilding craft, indicates that the former fragment was taken from the Rhodian's work. F. Jacoby was the first to surmise that the fragment in question paraphrases Callixeinus' text (cf. FGrH $627 \mathrm{~F}$ 2). It cannot be ruled out that Athenaeus or Callixeinus consulted official lists made during Ptolemy II's reign, since Appian of Alexandria certainly employed them in his writing (Praef. 10.41; he cites basilikai anagraphai), cf. van't Dack - Hauben 1978, 73, note 119; Murray 2012, 189. On credibility of Athenaeus' text and its source, see Rice 1983, 138-148, 152-154.

4 OGIS I 39. The information about Philadelphus building ships larger than 'fifteens' is also recorded by Pliny (NH 7.208). Papirological sources: Casson 1971, 140, note 17; Hauben 1987, 219-221.

5 Casson (1971, 140), Hauben $(1987,220)$, Rodriguez $(2000,24)$ and Murray $(2012,197-200)$ believe that the account describes the fleet as it was towards the end of Ptolemy II's reign. Grainger $(2010,101)$ proposes that the fleet enlargement program was carried out in the 270 s. 
fleet could only be met through funneling funds from overseas dominions. The expansion of the Ptolemaic power onto the Aegean islands and the coast of Asia Minor during the first clashes with the Seleucids shows that Ptolemy II remained aware of the need to balance the fleet's upkeep with an income drawn from newly conquered territories.

Few surviving sources speak of the activity of Ptolemy II's ground and naval forces, with even fewer mentions about operations of his Egyptian fleet, which were either unrelated or only peripheral to main war theatres in the Mediterranean. Since the Ptolemies successfully extended their international influence, the naval supremacy could have been politically expedient for the king of Egypt, but we possess too little evidence on local operations of the Ptolemaic fleet to weigh on that matter. One exception to this general scarcity of data on the Ptolemaic navy is an expedition sent to the Black Sea in the late 270s to support the city of Byzantion. As a consequence, the Ptolemies and Byzantion established friendly relations: Ptolemy II gifted the city with new land in Asia Minor, grain supplies, money and weapons, whereas the grateful Byzantines established Philadelphus' cult in their city. ${ }^{6}$ This noteworthy exchange of favors demonstrates that Ptolemy II used his navy to exert his influence in the Aegean world. ${ }^{7}$ We can conjecture that the Black Sea expedition addressed the threat of Galatan invasions faced by the Greek cities in the northern part of the Aegean. From Philadelphus' perspective, the local developments in the Aegean and Greece created an excellent opportunity to grab footholds in the region. Antigonus Gonatas in Macedonia consolidated his power after the death of his main rival, Pyrrhus, and imposed his rule over the majority of Greece, whereas the Lagids and the Seleucids after the First Syrian War began to fight for hegemony over the eastern part of the Mediterranean Sea. To have a powerful ally in this unstable region would benefit all major players in the struggle and Byzantion constituted one of the most influential city-states at the crossroads of the Aegean and the Black Sea. The Ptolemaic navy apparently also fought against piracy in the Aegean, their actions projecting a positive political image for the Ptolemies and creating goodwill towards Egypt; nevertheless, contrary to popular belief, no solid evidence exists to demonstrate that the Lagid fleet carried out regular large-scale antipiracy operations. Accordingly, caution should be exercised in reaching any conclusions about the Ptolemaic involvement in such raids. ${ }^{8}$

The Ptolemaic fleet under Philadelphus faced its greatest challenges when fighting in the Chremonidean (267-261) and Second Syrian (260-253) Wars. Why the former conflict broke out remains a subject of a lively scholarly debate. According to a popular yet contested theory, Ptolemy II largely continued the designs of his dead sister-wife, Arsinoe II: he attempted to either capture Macedonia for the Lagids or at least limit the

6 St. Byz. s.v. ö $\gamma \kappa v \rho \alpha$; Dion. Byz., Geographi Graeci Minori 2.34; see Habicht 1956, 116-121; Will 1979, 147; Grainger 2010, 91-92.

7 Ptolemy II, who adroitly employed propaganda to further his ends, used his navy to boost the Lagids' prestige in the world; for example, he sent expeditions to the Bosporan Kingdom or commanded Timosthenes of Rhodes to sail to the western ends of the Mediterranean Sea, cf. Fraser 1972, I: 522; II: 751, note 13.

$8 I G$ II $^{2}$ 650, ll. 15-16; XII 3.1291; XII 8.156; $S I G^{3}$ 502; cf. de Souza 1999, 53-54. Contra Ormerod 1924, 130-135 and Łoposzko 1994, 95. Both scholars believe that the Lagids had special squadrons, reportedly operating from a naval base on Thera (cf. Hölbl 2001, 43), that constantly patrolled the sea and fought pirates. However, no evidence exists to support such claims. 
Macedonian influence in Greece. ${ }^{9}$ The proponents of this interpretation draw attention to a fragment of an inscription with Chremonides' psephisma relaying Arsinoe's efforts to support the freedom of the Greeks, ${ }^{10}$ whereas its opponents argue that including a reference to the dead queen simply contextualizes Arsinoe's place in Ptolemy II's propaganda rather than reveals her lasting posthumous influence on her brother's foreign policies. ${ }^{11}$ One way or another, Ptolemy must have found it fitting to present his dead sister as a divinized protectress of his activity in the Aegean; the text of the inscription shows that, not unlike his father in 308, Ptolemy II embroiled himself in the war under the pretence of freeing Greek poleis subjugated by Macedonia. ${ }^{12}$ According to another theory concerning Ptolemy II's reasons for starting the Chremonidean War, Antigonus Gonatas increased the number of ships the Macedonian fleet, ${ }^{13}$ directly challenging the Ptolemaic naval supremacy in the Aegean; furthermore, Gonatas consolidated his power after Pyrrus' death and thus accumulated enough political capital to vie with the Ptolemies for hegemony over the Mediterranean. Markedly, the Macedonians have previously made inroads into controlling the Aegean. Gonatas' father, Demetrius Poliorcetes, and grandfather, Antigonus Monophthalmus, established the League of the Islanders that united Cycladic poleis and created another controllable faction in the region; unfortunately for the Macedonians, the Lagids seized control over the League after Demetrius' defeat.

No matter what the Ptolemaic rationale for engaging in the Chremonidean War, continental Greece apparently formed the main theater of war; however, scant surviving information about the war's outcome implies that, as I suppose, Ptolemy II used the war primarily to extend his influence in the Aegean, and not in Greece or in Macedonia. Granted, the available evidence for this interpretation remains limited. Very few literary sources provide accounts of the war (with a mere handful of mentions in Pausanias

9 Bouché-Leclerq 1903-1907, I, 188; Tarn 1913, 290-296; Bevan 1927, 67; Huss 2001, 274; Errington 2008, 88; Hauben 2014, 261. It is not certain whether the man who appears in Egyptian documents from this period should be identified as Ptolemy II's co-regent, since he might have been - as supporters of this identification usually presume-Arsinoe II's son from her earlier marriage to Lysimachus. Alternatively, the unknown man could have been either (1) Ptolemy II's son, ascending to the throne as Ptolemy III after his father's death, (2) an otherwise unknown son of Philadelphus from his first marriage, or (3) a bastard born out of one of Philadelphus' numerous mistresses. On Ptolemy "the Son," see de Groot 1917-1918; Huss 1998; Domingo Gygax 2000; Domingo Gygax 2002; Tunny 2000; Coşkun 2016, 215-216, 225.

10 IG II 687, ll. 16-17 = StV III 476.

11 Cf. Paschidis 2008, 168; Carney 2013, 93.

12 Cf. also Dmitriev 2011, 136; Caneva 2013, 280-311; Kralli 2017, 128-129. For the place of Arsinoe (and especially her cult) in Ptolemy II's propaganda, see Müller 2009, 266-300, 353-379; Grabowski 2014. Arsinoe's posthumous influence on her brother's politics, especially during the outbreak of the Chremonidean War, has been greatly exaggerated (e.g. Bouché-Leclerq 1903-1907, I: 188; Tarn 1913, 262, 293-296; Bevan 1927, 61, 64; Macurdy 1932, 111-130; Longega 1968, 83-95). For Arsinoe's role in the Ptolemaic politics, see Burstein 1982; Hauben 1983, 99-111, 114-127; Carney 2013, 91-95.

13 Heinen 1972, 97-100 (with caution, admits that both hypotheses are likely); Will 1979, 219-221; Hammond - Walbank 1988, 279; Hölbl 2001, 41. Historians have also proposed other reasons for the outbreak of the Chremonidean War, such as economic grounds. Tarn (1913, 219-221) stressed Athens' dependence on grain supply from Antigonus and Ptolemy; in his opinion, the Athenians might have wanted to tighten bonds with the Lagids and thus safeguard deliveries of Egyptian grain. Rostovtzeff (1941, I: 215-216) considered the possibility that Antigonus wanted to develop Piraeus into a bustling trade centre which could compete against Delos, Rhodes, Miletus and Ephesus (all firmly on the Ptolemies' side) and hence supposedly provoked Ptolemy II into action. However, surviving sources neither prove nor disprove any of these theories. 
and Justin ${ }^{14}$ ). Nevertheless, surviving inscriptions and archaeological finds shed light on some of the war's key events and indicate that the Ptolemaic activity in this conflict centered around the Egyptian naval commander Patroclus. Having landed in Attica with his fleet, the Ptolemaic strategos ${ }^{15}$ lacked manpower to carry out frequent operations on land, imposing the burden of war effort by and large on his Greek allies. ${ }^{16}$ Should we assume that Ptolemy's goal was indeed to take control over Greece and then to reach for Macedonia, it is difficult to explain why such a small naval force was dispatched for such a task. ${ }^{17}$ The expedition of 308, commanded personally by Ptolemy I, has clearly shown that the ambitious Ptolemies would need a sizeable fleet should they want to conquer Greece. ${ }^{18}$ Relevantly to the matter at hand, Pausanias points to the inadequacy of Ptolemy II's force $(1.7 .3 ; 3.6 .5)$, writing that Patroclus justified his limited activity on land through supposedly being short on manpower, having only Egyptians and sailors at his disposal. Nonetheless, Pausanias' account either remains unaware of or does not take into the consideration Ptolemaic garrisons Patroclus may have left on some Aegean islands. ${ }^{19}$ If Patroclus had indeed dispersed a fraction of his forces across the Aegean, then he arguably should have left a contingent to defend him in Attica, their presence implied by the text of an inscription from Rhamnus. ${ }^{20}$ However, a presence of a small contingent does not equal any significant Ptolemaic involvement in the war theater in continental Greece. ${ }^{21}$ Pertinently, leaving garrisons on Aegean islands would deplete the expeditionary forces for land operations in Greece, which I take to argue that the main Ptolemaic goal in this war was not winning dominion over continental Greece.

Even if the material evidence for the Ptolemaic presence in Attica during the Chremonidean War remains scant and inconclusive, some reasonable conclusions may be drawn. Surveys in the Athenian hinterland identified a number of fortifications whose construction or expansion is linked to the Chremonidean War. ${ }^{22}$ In contrast, finds of Ptolemaic coins in Attica in the archaeological context dated to the war do not necessarily prove that they were lost or deposited by Ptolemaic forces operating there; it is just as likely that finds of Ptolemaic coinage in Attica testify to passive financial support provid-

14 Paus. 1.1.1; 1.7.3; 3.6.4-6; Just. 26.2.1-8. Brief mentions about individual episodes from the Chremonidean War can also be found in Plut., Agis 3.4; Polyaen. 4.6.20.

15 Pausanias (1.1.1) erroneously calls Patroclus a nauarchos, but Launey (1945, 36-38) proves that Patroclus held the official title of strategos. See also Heinen 1972, 142-143; Hauben 2013, 53-54.

16 For Patroclus' land operations in continental Greece, see Heinen 1972, 167-181; Dreyer 1999, 318$331,342-370$.

17 Pausanias confirms that the Egyptian expeditionary force was rather small (1.7.3; 3.6.5). O'Neil $(2008,74)$ questions Pausanias' veracity in this regard, but other sources on the unfolding course of events also hint at the Ptolemies limiting their military involvement on land.

18 For Ptolemy's expedition of 308, see Grabowski 2008, 40-44; Hauben 2014, 251-259.

19 See below.

20 SEG 24.154; 40.135 (editio princeps: Petrakos 1967; revised text: Robert 1968, 456-460, no 247); Heinen 1972, 152-154. The text of the inscription mentions the term stratiotai in reference to Ptolemaic soldiers. Hauben $(2013,61)$ is probably right to assume that the term nautai, used by Pausanias (3.6.5), should be interpreted as epibatai (i.e. not sailors per se, but soldiers who served on ships).

21 Contra Habicht 1997, 144-145; O’Neil 2008, 74-75.

22 Vanderpool - McCredie - Steinberg 1962; McCredie 1966. Which of these fortifications should be linked to the Chremonidean War remains a contentious topic: see Vanderpool - McCredie - Steinberg 1964; Heinen 1972, 159-167; O’Neil 2008, 74-78. 
ed by Ptolemy II to his Greek allies, e.g. in order to recruit mercenaries. Crucially, even if some of inland Attic fortifications identified as Ptolemaic in origin, such as the camp at Heliupolis and the fort on the Hymettos, may have once housed Ptolemaic troops ${ }^{23}$ all such inland installations were soon abandoned. ${ }^{24}$ It is more likely that Patroclus' soldiers manned coastal bases in Attica, since Ptolemy II focused his efforts on naval operations, whereas the most important port in the region, Piraeus, probably remained under Macedonian control, ${ }^{25}$ forcing Patroclus to establish naval bases in other parts of Attica. If this reasoning holds true, then sites of finds of Ptolemaic pottery and coins on the Attic coast are the most likely to have given shelter to the Egyptian forces. Their presence, however, may be confirmed only at sites where material evidence pointing to their occupation is corroborated by other sources, such as in Rhamnus on the north-eastern coast of Attica. Another similar site on the eastern Attic seaboard, a peninsula jutting out into the Aegean once known as Koroneia and today as Koroni, became an important naval base for Patroclus' forces. The sea-facing fort by a large bay remained isolated from the interior of the peninsula. ${ }^{26}$ The Egyptian forces most probably used Koroni to move supplies to Athens and thus avoid the region of Piraeus, controlled by Antigonus Gonatas. ${ }^{27}$ Other sites convincingly linked to Patroclus' expedition include the present-day site of Vouliagmeni on the south-western Attic coast (ca. $20 \mathrm{~km}$ south of Athens) and perhaps the fortifications on the Kynosura peninsula on the north-eastern Attic coast (south of Rhamnus). ${ }^{28}$ Finally, Patroclus established and fortified his main base on an islet not far from the southern tip of Attica, later named after the camp (Patroklou Charax, presentday Gaiduronisi). ${ }^{29}$ It cannot be ruled out that Patroklou Charax, linked with coastal fortifications to the north (in the deme of Atene) enabled the Egyptians to neutralize the Macedonian garrison stationed at Sounion. ${ }^{30}$ Another chain of islets situated by the coast of Attica between Aegina and Methana, the so-called Pelops' Islands, owe their name to

23. Scholars supporting this interpretation: Huss 2001, 276; O’Neil 2008, 74-75; cf. also Rodriguez 2000, $23-28$.

24 Hauben 2013, 61.

25 We cannot be completely certain who had control over Piraeus during the Chremonidean War. Even if Patroclus did not use it as his naval base, Pireus may not have necessarily been controlled by the Macedonian forces or blockaded by Antigonus' fleet. Beloch $(1927,453)$ concluded that the Athenians might have simply refused to establish an Egyptian naval base within the port for fear of Patroclus taking advantage of Athens and capturing it for the Ptolemies. However, Beloch's reasoning must be rejected, since it would have been extraordinary for the Athenians to hinder their most important ally's navy, with the effectiveness of the Ptolemaic army largely dependent on having a conveniently located naval base. Dreyer (1999, 354-355) proposed that Piraeus remained under Athenian control but its use by the Ptolemaic fleet was encumbered by the forces of Gonatas occupying a significant portion of Attica. It seems, however, that Piraeus pincered by Gonatas' forces would still stand for a more convenient base for Patroclus' fleet than the ones that he ultimately used during the war. In light of all of the above, it appears that Piraeus fell into Antigonus' hands: Habicht 1979, 95-107; Buraselis 1982, 158; Garland 1987, 51-52; Huss 2001, 275; O’Neil 2008, 71-72.

26 O’Neil 2008, 74-75; cf. also Vanderpool - McCredie - Steinberg 1962; Lauter-Bufe 1989.

27 The existence of a roundabout supply chain that would link Athens to Koroni and bypass Pireus is corroborated by finds of Ptolemy II's coins in Markopoulou, mid-way between Koroni and Athens (see O'Neil 2008, 75).

28 McCredie 1966, 30.

29 Paus. 1.1.1. Cf. Strabo 9.1.21; McCredie1966, 18-25.

30 No information survived about who controlled Sounion during the war. We can safely assume, however, that it was not a Ptolemaic site: had Ptolemy's allies controlled Sounion, Patroclus would have established 
a Ptolemaic officer serving under Patroclus, ${ }^{31}$ which suggests that these islands served as a base for the Ptolemaic forces operating in the region. Patroclus' most important military success was the capture of Methana in Argolid (then renamed Arsinoe), the only long-lived Ptolemaic enclave in continental Greece (controlled by the Lagids until 145), with Patroclus possibly to be credited with renaming the city. A strategically important site on a peninsula protruding into the sea, Arsinoe/Methana received a Ptolemaic garrison and became a naval base that enabled the Ptolemies to control traffic in the Saronic Gulf. ${ }^{32}$

Even if some evidence survives on Patroclus establishing encampments and naval bases across Attica, very little information surfaced about Ptolemaic operations in the coastal waters of continental Greece, the same holding true for the Macedonian navy. Exacerbating the problem is the relative paucity of sources on the $260 \mathrm{~s}$ and $250 \mathrm{~s}$, the said interval being arguably the worst attested one in the entire Hellenistic period. Only some fragmentary information survives about minor naval confrontations off the coasts of Kos, Andros, and near Ephesus: the silence of the sources suggests that no major sea fighting took place in the coastal waters of Attica and the Peloponnese. What survives allows us to draw some tentative conclusions. We are certain that the Macedonian fleet blockaded Attica. The text of the inscription from Rhamnus testifies to an increase in pirate activity in this part of the sea and suggests that the Egyptian fleet was unable to handle this danger efficiently; the text honors the Athenian general Epichares for defending the inhabitants of this deme and collecting the ransom for members of the community seized by pirates. ${ }^{33}$ It remains an open question whether the pirates simply grasped an opportunity to plunder the Attic coast or they acted on behalf of Antigonus Gonatas. In any case, piracy undoubtedly plunged the region into turmoil, encumbered military operations of the Athenians and their allies, and disrupted supply lines for besieged Athens. ${ }^{34}$ The Athenian fierce resistance and tenacity under siege may in turn hint at Patroclus initially managing to deliver at least some supplies to the surrounded city. Cutting off the supply line towards the end of the war and the resultant hunger informed the Athenians' decision to capitulate to the Macedonian army. ${ }^{35}$ Therefore, Patroclus' supply line to Athens must have eventually been disrupted by the Macedonian blockade.

his base here, in lieu of setting up a camp on Patroklou Charax. Cf. McCredie 1966, 112; Heinen 1972, 159; O’Neil 2008, 74.

31 Paus. 2.34.3. For more detail on the nesides Pelopos, see Herbst 1937, 392-393. Pelops was probably Patroclus' officer: Bagnall 1976, 83-84.

32 It is not altogether clear when exactly the Ptolemies seized Methana, but the available evidence points to the Chremonidean War. For Methana, cf. Meyer 1935, 1375-1379; Bagnall 1976, 135-136; Cohen 1995, 124-126; Gill - Foxhall - Bowden 1997, 68-76.

33 SEG 24.154.

${ }^{34}$ O'Neil $(2008,76)$ argues that ransoming kidnapped Athenians indicates that the pirates acted independently and not as Antigonus' privateers. Agreements between Antigonus and local pirates notwithstanding, privateers still needed revenue from kidnapping and ransoming local population. For piracy in the vicinity of Rhamnus, see Oliver 2001, 142-148.

35 Polyaen. 4.6.20. Cf. Paus. 3.6.6; Apollodoros, FGrH 244, F 44. Prior to Athens' ultimate capitulation, a short-lived peace had been signed between Gonatas and Athens (Polyaen. 4.6.20). The Athenians accepted the steep terms of Antigonus' peace proposal at that time, even though they could have theoretically waited Antigonus out, since he had to deal with an invasion of Alexander II, the king of Epirus (Just. 26.2.9-11). The Athenian submission indicates that the famished city could not stand Antigonus' blockage any longer. 
Some interesting detail on the conflict comes from the text by Phylarchus, who records that Patroclus sent large fish and green figs to Antigonus' camp..$^{36}$ Due to the fragmentary state of Phylarchus' work, the context of this gesture remains unknown to us. Historians almost unanimously agree that naming Patroclus dates this episode to the Chremonidean War. Since contextualizing this episode depends on the date of the naval battle off the coast of Kos, a small subset of scholars also argues for a later dating, ${ }^{37}$ although such an interpretation poses certain problems. If the episode occurred during the Chremonidean War, then Patroclus perhaps wanted to foment unrest among the Macedonian units by showing his advantage through displaying the freshness and quality of his provisions. In this case, such a provocation would serve to undermine the Macedonians' confidence, help his Greek allies in land battles, and, eventually, end the Macedonian siege. ${ }^{38}$ If that was Patroclus' intention, then Antigonus skillfully thwarted his plan: in his interpretation, Patroclus' gifts actually encouraged the Macedonians' to win hegemony at sea so as he would not have to survive solely on figs. Patroclus' gesture could also be interpreted as a challenge meant to emphasize the Ptolemaic thalassocracy, with Patroclus' derisive gesture indicating that the Ptolemaic fleet at the time had advantage at sea. ${ }^{39}$ In light of evidence from other sources, Phylarchus' anecdote elucidates the Ptolemaic and Macedonian maritime strategies in the War. Antigonus had just began to enlarge his fleet and could not undertake large-scale operations. It cannot be ruled out that the Ptolemaic commander wanted to provoke underprepared Antigonus into fighting a major naval battle. Patroclus, aware of his advantage, might have wanted to nip in the bud Antigonus' potential threat to the Ptolemaic supremacy at the Aegean Sea. At that stage of the conflict, a Ptolemaic victory over Antigonus' fleet would have had a great symbolic significance for the land offensive but would have primarily served to strengthen the Ptolemaic thalassocracy. The available evidence indicates that Ptolemy II did not engage a very large military force to help his allies in Greece. On the other hand, there are grounds to claim that he did not hesitate to take the opportunity to strengthen his position in the Aegean Sea. Patroclus' activities in the Aegean region lead us to the question whether Ptolemy II's main goal in the Chremonidean War was to expand his local network of naval bases in the Aegean and thus control the region.

A number of surviving sources, usually linked to the Chremonidean War, communicate Patroclus' activities on the Aegean islands. Historians who reconstruct the course of events in this conflict frequently assume that the Ptolemaic strategos leapfrogged across the islands to reach Attica. ${ }^{40}$ As an aside, the chronology of these events is not completely certain, with Patroclus possibly having previously visited some of the islands during his Attic campaign. The relative chronology of Patroclus' movements notwithstanding,

36 Phylarchos, FGrH 81, F 1 = Athen 8.334a-b.

37 So e.g.: Heinen 1972, 191-192; Buraselis 1982, 159; Gabbert 1983, 135; Dreyer 1999, 362; Huss 2001, 278. Hammond - Walbank $(1988,597)$ date this event to a period before the battle of Kos, which in their view took place in 255 .

38 Huss 2001, 278-279. For the Greeks considering figs as the cheapest and commonest kind of food, see Olck 1909, 2103-2104, 2135-2137; Buraselis 1982, 159.

39 Cf. Heinen 1972, 191-192; Buraselis 1982, 159; Dreyer 1999, 362-363, note 307; 371-372.

40 Launey (1945) was the first to propose such an interpretation. Similarly, e.g. Marek 1984, 319; Hölbl 2001, 42; Huss 2001, 275. 
Ptolemy II and his advisers recognized the significance of this region and the need to maintain contacts and strengthen the bonds tying the Aegean islands to the Lagids. More significant to this paper is how far the Ptolemaic influence extended in the insular poleis reached by Patroclus. Testimonies about the strategos' contacts with individual cities on the Aegean islands refer to various aspects of their relations. Out of islands visited by the Ptolemaic expedition, Crete held a special place due to its strategic location. Other sources confirm that Patroclus' visited two local Cretan poleis, Itanos and Olus. Itanos honored Patroclus with its citizenship in recognition of his involvement in resolving the city's internal and foreign problems. At Olus, Patroclus and other Ptolemaic officers were given the titles of proxenoi and euergetai. ${ }^{41}$ Since the Cyclades occupied a central place in the Ptolemies' Aegean policy, Patroclus unsurprisingly visited both Thera and Keos. ${ }^{42}$ His actions in these locations differed from his involvement on Crete, but they always established or cultivated harmonious relations between local poleis and the Lagids. In context of the rivalry in the Aegean Sea, what truly matters is whether Patroclus visited Aegean islands to build friendly relations and extend the Ptolemaic influence or he came to incorporate islands lastingly into the Lagid domain, leaving behind manned garrisons or official representatives of the Ptolemies on every island he visited.

In the case of Crete, both Itanos and Olus could have been conveniently-located, easily defended bases. The available evidence does not confirm that Patroclus left behind permanent Ptolemaic garrisons in either of these poleis, although it appears almost certain that some part of his force was left in Itanos. ${ }^{43}$ From this point onward, Itanos found itself in the sphere of the Ptolemaic influence and became one of the most important naval bases. ${ }^{44}$ It is very likely that the Ptolemaic influence also extended to the Cretan cities of Rhithymna and Aptera. ${ }^{45}$ Patroclus' gain of a foothold on Crete carried much weight for the Ptolemies, since the body of extant evidence demonstrates that the dynasty under Ptolemy I and at the beginning of Ptolemy II's reign had not fostered close relations with

41 I. Cret. I.22.4; III.4.2; 3. Relevantly, our sources communicate that Patroclus had reportedly captured and executed the poet Sotades, not far from the southern coast of Crete, near the small island of Kaudos. The poet had been wanted by Ptolemy II for derisive comments about the king and his sister-queen, Arsinoe II. Athenaeus (14.621a), quoting Hegesandrus, names Kaudos as the place of the execution; if we accept Athenaeus' version, the event could not have taken place during the Chremonidean War. Launey (1945) offered a convincing argument for Kaudos and his theory was commonly accepted by historians. Recently, Hauben has presented some arguments in defence of Athenaeus' text and against Kaudos as the place of execution (2013, 64-65), but the matter has not been resolved.

42 IG XII $3.320=$ OGIS I.44; IG XII 5.1061. Whether Patroclus visited Delos during this campaign remains debatable. Patroclus consecrated a phiale on the island (see. PP VI, no 15063), with the inventory from Delos ( $I G$ XI 2.226 B) dating this consecration to a period before 257. A more precise dating of this event eludes us.

43 Spyridakis 1970, 71; Bagnall 1976, 321; Marek 1984, 319; Paschidis 2008, 461; Huss 2011, 177. Cf. Heinen 1972, 144-146; Hauben 2013, 54.

44 Neither entire Crete nor any of its parts were ever under the direct administration of the Ptolemies or under the control of their representatives. Among the Cretan cities connected to the Lagids, Itanos distinguished itself not only due to the Ptolemaic garrison stationed there: many sources suggest that Itanos remained Egypt's exclusive partner, having no relations with other Hellenistic powers until the reign of Ptolemy VI: Kreuter 1992, 25. For the status of the island and its poleis in the Ptolemaic empire, see Spyridakis 1970 , 69-103; Bagnall 1976, 117-123; Huss 2011, 177-178.

45 This interpretation is corroborated by an extant list of officers who received the titles of proxenos or euergetes, cf. Marek 1984, 320. 
any Cretan poleis. ${ }^{46}$ Crete, of an enormous strategic importance for the rivalry in the Aegean Sea and in Greece, lies on the crossroads of sea roads connecting Egypt, Syria, Greece, Asia Minor and Cyrene. Significantly, many Cretans joined the armies of Hellenistic rulers as mercenaries or became pirates, frequently plundering coastal communities of the Mediterranean in the Hellenistic period. For abovementioned reasons, the Ptolemaic diplomatic policy was to foster friendly relations with Cretan poleis. ${ }^{47}$ We do not know whom every individual Cretan polis supported in the Chremonidean War, ${ }^{48}$ but Patroclus' achievements - developing diplomatic relationships with Cretan poleis and, probably, stationing a permanent garrison in Itanos - constituted considerable successes for the Ptolemies.

In the context of the Hellenistic rivalry in the Aegean world, the Cycladic islands of Keos and Thera mattered to the Ptolemies just as much as Crete did. The former island, located near the southern point of Attica, had an excellent port and was an ideal foothold in this part of the Aegean Sea, especially in the context of the Antigonids controlling Euboea. Keos, a relatively large island with four poleis, had attracted the Lagids' interest before, ${ }^{49}$ having been a member of the League of the Islanders (of great significance to the Ptolemaic policy in the Aegean) before the outbreak of the Chremonidean War. Thera, another island crucial to the Ptolemaic policy in the Aegean, does not feature in the contemporary sources concerning the League of the Islanders, although its participation is almost certain. Patroclus' visits to Thera and Keos and garrisoning them with Ptolemaic forces constituted important steps towards strengthening the Ptolemaic thalassocracy in the Aegean. ${ }^{50}$ In accordance with Ptolemy II's policy and propaganda,

46 It cannot be ruled out that Ptolemy I had already established such contacts with certain Cretan communities, but no sources exist to support this conjecture. Spyridakis $(1970,72)$ draws attention to testimonies concerning Cretan mercenaries serving the first Lagid. However, these neither link them clearly to the king (Launey 1949-1950, I: 249), nor do they confirm Soter's direct contacts with Crete. Also problematic is the wording of the inscription about the foundation of a temenos at Itanos for Ptolemy III and Berenice II (I. Cret. III.4.4); the foundation could be used to argue that the celebrated pair's ancestors (or, indeed, Ptolemy I) already wielded direct influence in the city (Spyridakis 1970, 76; Paschidis 2008, 460), or, alternatively, the mention of Ptolemy III and Berenice II had a purely panegyric character and did not refer to any actual tie between Itanos and Ptolemy I (Kreuter 1992, 21). Itanos could not have hosted any Ptolemaic garrison before Patroclus' arrival, since it was Patroclus who was credited with resolving Itanos' internal problems. Relevantly, an enkomion in honour of Ptolemy II, written in the mid-270s, lists lands under his reign, omitting Crete or its poleis while including the Cyclades (Theocr. Id. 17.85-90). For the dating of this work, see Hunter 2003, 3-7.

47 Cf. Kreuter 1992, 17-46. For Cretan pirates, cf. Brulé 1978; de Souza 1999, 80-84.

48 Epigraphic sources confirm that some Cretan cities sided with the anti-Macedonian coalition $\left(S I G^{3}\right.$ 432). Cardinali (1904) and Marek $(1984,319)$ convincingly argue that the Cretans favored both sides of the conflict (although we cannot uncritically accept every conjecture of Cardinali about which polis favored whom). In any case, no evidence points to Antigonus Gonatas establishing ties with Cretan cities. The Macedonian alliances forged with Eleutherna and Hierapytna could have been the work of Antigonus Doson, cf. StV 501, 502; Kreuter 1992, 47-48.

49 IG XII 5.1065

50 Garrisons on Keos and Thera almost certainly date to Patroclus' expedition, cf. Bagnall 1976, 141142; van’t Dack 1988, 125-126; Cherry - Davis 1991, 16-18; Paschidis 2008, 433; Hauben 2013, 56-58. For the advantageous position of the port in Koresia on Keos, see Robert 1960, 146-160. 
the most important Kean port, Koresia, changed its name to Arsinoe, probably through Patroclus' efforts, reflecting the sway the Ptolemies had over the island. ${ }^{51}$

Samos in the eastern Aegean was another island important to the Ptolemaic diplomacy and naval power during the Chremonidean War. To control Samos, conveniently located off the west coast of Asia Minor, meant to control coastal waters near bustling ports in Asia Minor (from Erythrai to Halicarnassus to Knidos) and waters between islands from Chios to Rhodes. Samos came under the Lagids' control towards the end of the 280 s and became one of their largest naval bases. ${ }^{52}$ Accordingly, the Ptolemies expended considerable effort to cultivate relations with this polis in the face of war and the Samians reciprocated their effort by celebrating Ptolemaic commanders. At an unspecified point in time, probably during the Chremonidean war, the Samians erected Patroclus' statue, ${ }^{53}$ also honoring another high-ranking Ptolemaic officer, Pelops. ${ }^{54}$ As discussed above, Pelops probably accompanied Patroclus during his expedition to Attica, with his name given to a chain of islets off the coast of the Peloponnese near Arsinoe/Methana. ${ }^{55}$ The evidence on Samos and in other Ionian cities indicates that this area, a war theater of secondary importance to Antigonus and Ptolemy's Greek allies, mattered much more to the Ptolemies themselves. Philadelphus' activities in Ionia, about which little survived, seem to have focused on securing new ports for his naval bases and winning allies for his cause. Ptolemy II seized Ephesus (perhaps making it, for a time, the key Ptolemaic base in Ionia ${ }^{56}$ ), might have extended his influence to Lesbos, ${ }^{57}$ and fostered closer relations with Miletus, another significant Egyptian naval base in the eastern part of the Aegean. ${ }^{58}$ The brewing conflict of the Chremonidean War brought about some, but not all, of these acquisitions. In the case of Ephesus, Ptolemy II primarily took advantage of the

51 Cf. Bagnall 1976: 142; Cherry - Davis - Matzourani 1991, 240; Cohen 1995, 137-138; Mueller 2006, 65.

$52 S I G^{3}$ 390. The inscription contains the text of a decree issued by the council of the League of the Islanders, related to Ptolemy II establishing the festival of Ptolemaia, which honored his dead parents. However, the text does not indubitably confirm that Samos was a member of the League of the Islanders. According to Polybius (5.35.11), Samos was the main base of the Egyptian fleet under Ptolemy IV's reign. Another Ptolemaic naval base in the vicinity of Samos was Halicarnassus (P. Cair. Zen. 59036).

53 Tracy (1990, 64, 67-68), reasoning on grounds of paleography, claimed that the inscription on the base of Patroclus' statue was carved by a stonecutter active ca. 305-270, with Tracy dating the inscription to the 270 s. However, a tentative 270 s dating could very well coincide with the early phase of the Chremonidean War, which broke out soon after (Heinen 1972, 151; Hauben 2013, 59).

54 IG XII 6.119.

55 Cf. above note 31. Bagnall (1976, 83-84) believes that Pelops could not have been the general of the Samian garrison, since he must have had authority over a larger area. Rodriguez (2000, 27-28) supposes that Pelops could have been the commander of the entire Ptolemaic fleet in the eastern part of the Aegean Sea.

56 Cf. Habicht 1956, 91-92; Crampa 1969, 17, note 21; Orth 1977, 130-131; Piejko 1991, 147, contra Seibert 1976, 47, 55; extrapolating from an unconvincing interpretation of one of the inscriptions (I. Labraunda 3, 4-6). Seibert conjectures that the Seleucid rule over Ephesus continued uninterrupted until the mid-250s.

57 Cf. Brun 1991, 106-108; Labarre 1996, 54-55.

58 I. Milet 139; RC 14. The inscription in question dates back to $c a$. 262/261. Callicrates of Samos, another Ptolemaic general distinguished for building the Lagids' position in the Aegean, played a decisive role in the events at Miletus. For Callicrates, see Hauben 1970, 33-70; 2013, 45-52. Miletus maintained ties with Ptolemy II at least from ca. 280 (I. Milet 123), but the city's first friendly contact with the Lagids' envoys dates back to the times of Ptolemy I. Cf. Seibert 1971; Bagnall 1976, 171; Huss 2011, 171; Marquaille 2008, 46 , note 29 . 
Seleucids embroiling themselves in a conflict with Pergamon. ${ }^{59}$ In a letter to the inhabitants of Miletus, Ptolemy II thanked the citizens of this polis for their loyalty in the face of a threat from the land and sea, which might echo local poleis opposing Macedonian policies. The events in the eastern part of the Aegean Sea may indicate that Ptolemy II intended to begin the Chremonidean War in order to strengthen the dynasty's influence at sea, with land battles in Greece merely meant to hinder Antigonus' response to the Ptolemaic conquests in the Aegean. As I demonstrated, Philadelphus' effort, after all, concentrated on winning over the Aegean islands.

The outcome of the Chremonidean War did not favor the Lagids, who clashed with the Antigonids and suffered a defeat in continental Greece - and a concomitant loss of prestige. Although this failure could have seriously hampered the Ptolemaic power in this region, Ptolemy II apparently took advantage of a period of post-war upheaval in Greece to further his interests. After the war, Antigonus Gonatas lost much of his former support due to implementing unpopular policies, whereas minor states of continental Greece began to federate, establishing the Aetolian League and the Achaean League. ${ }^{60}$ During the Chremonidean War, the Lagids not only strengthened their position in the Aegean but, more significantly, they also established their longest-occupied naval bases in that region (Itanos, Thera and Arsinoe/Methana), which they kept until the very end of the Ptolemaic presence in the Aegean, i.e. their evacuation by Ptolemy VIII in 145. If, as I argued, Ptolemy II's military goals in the Chremonidean War did encompass extending his influence in the Aegean then, despite having nominally lost to the Antigonids, Philadelphus obtained some of his goals: he won enduring support of numerous insular Aegean poleis and captured ports in Ionia and southern Asia Minor.

The Lagids truly suffered from the Macedonian hands only in the Second Syrian War, which, as the Chremonidean War before it, is known to us only from scant surviving evidence. Relevantly to this article, available sources mention only a few naval incidents of the Second Syrian War. The Ptolemaic naval power faced a triple challenge. First, Ptolemy 'the Son', most probably the overseer of the Ptolemaic possessions in Ionia, rebelled against his father Philadelphus and thus deprived the Ptolemies of a part of their fleet. Second, the newly ascendant Macedonia joined the war and turned its attention to the Ptolemies. ${ }^{61}$ Third, the Rhodians, who had one of the strongest fleets in the Aegean Sea, chose to side with the Seleucids and against the Ptolemies. Ptolemy II's son, residing in Ephesus, harbored a personal ambition of ruling an independent kingdom in Asia

59 In 263, Eumenes I took over power in Pergamon. Unlike his predecessor, Philetairus the Seleucid loyalist, Eumenes swiftly pursued an anti-Seleucid policy, and ca. 261 he secured a victory over Antiochus I in a battle fought near Sardes (Strabo 13.4.2).

60 Towards the end of the Chremonidean War, in 262/261, the Delphic Amphictyonic council (in which the Aetolians had the majority) declared that the Lagids' most important dynastic festival, the Alexandrian Ptolemaia, acquired the status of Panhellenic games (FD III $4.357=$ CID 4.40). Starting from 250/249, Ptolemy II began to offer financial support to the Achaean League (Plut. Arat. 9-15). The Lagids also devoted their attention to the Aetolian activity in the Aegean Sea in the 250s and 240s, cf. Grabowski 2010, $201-207$.

${ }_{61}$ The dating of the battle near the coast of Kos is a subject of an ongoing debate; the most likely suggestions are 261 or 255, cf. Tarn 1909; Bikerman 1938: 371; Peremans 1939; Heinen 1972: 193-197; Buraselis 1982: 146-151; Reger 1985; Hammond - Walbank 1988: 595-599. This is written with an assumption that the battle of Kos took place in the 250s, since no additional information exists about Antigonus Gonatas' involvement in the conflict. 
Minor carved out of his father's domain, which led him to rise up against Philadelphus. He found an ally in the Aetolian Timarchus, who seized Miletus and Samos. ${ }^{62}$ In result, Ephesus, Miletus and Samos, three most important footholds of the Ptolemaic naval power on the east coast of Asia Minor, slipped out of the Egyptian control. Even though rebellious Ptolemy the Son was soon murdered, the Ionian turmoil endured. Ptolemy the Son's erstwhile supporter, Timarchus, found himself exiled from Miletus after the Milesians summoned Antiochus II to remove him. Antiochus exploited the resultant power vacuum in Ionia, directing his army to capture the Samian land possessions and allying himself with the Rhodians. ${ }^{63}$ We do not know what spurred Rhodes to turn against the Ptolemies, their traditional protectors; perhaps the Rhodians, possessors of a large fleet, began to fear the Ptolemaic thalassocracy. ${ }^{64}$ Fittingly, it was the Rhodian fleet that landed the first blow against Philadelphus' naval power. Naval forces of Rhodes, commanded by Agathastratos, surprised and defeated the Ptolemaic fleet under Chremonides in a battle near Ephesus ca. 258. ${ }^{65}$ In the aftermath of this defeat, Antiochus II most probably seized Ephesus for himself; ${ }^{66}$ with this third (after Miletus and Samos) Ptolemaic naval base in the eastern Aegean falling prey to the Seleucids, the Egyptian fleet lost a significant portion of its former port infrastructure in this region.

Assuming that the battle of Kos was indeed fought circa 255, then this resounding victory by Antigonus Gonatas delivered the second blow against the Ptolemaic naval power. Though no direct information survives about Antigonus' participation in the Second Syrian War on land, his involvement in the conflict is very likely; at the time, he was, at least formally, Antiochus II's ally, with two rulers also bound by family ties. ${ }^{67}$ Antiochus' appropriation of Ephesus, Miletus and Samos indicates that the Antigonids and the Seleucids could have cooperated in ousting Ptolemaic navy out of the Aegean. We know little about operations of the Ptolemaic fleet during the Second Syrian War; the topography of the region and the distance between main battle sites implies that ships were used for transporting armies and supplies, with some of the attacks mentioned in

62 Pomp. Trog. Prol. 26; Front. Strat. 3.2.11. It remains contentious whether Ptolemy "the Son" resided in Ionia since the end of the Chremonidean War as the commander-in-chief of Ptolemaic possessions in Asia Minor - or, alternatively, he came to Ionia only after he had rebelled against Philadelphus. Some evidence supports the latter interpretation, since available sources imply that the Ptolemaic commander-in-chief of possessions in Asia Minor at that time was Chremonides, who assumed the position ca. 262/261, cf. Coşkun 2016, 220-221, 225.

$63 I G$ XII 6.11 = SEG 1.366; Athen. 13.593a-b; App. Syr. 65.344. For Samos, cf. Hallof - Mileta 1997, $280-283$.

64 Cf. Berthold 1984, 91 (who believes that the Rhodians disliked Ptolemy because of his employing privateers during the First Syrian War, as indicated by Pausanias' account - 1.7.3). Perhaps the RhodianPtolemaic rivalry also stemmed from their conflict of interest over Caria, cf. Reger 1994, 43.

65 Lind. Temp. Chron. 37; Polyaen. 5.18; Front. Strat. 3.9.10. For the battle of Ephesos, cf. Crampa 1969, 115-117; Seibert 1976; Berthold 1984, 89-90.

66 Reconstructing the sequence of events and their chronology, i.e. combining incongruent accounts of Polyaenus and Frontinus, poses significant problems, cf. Crampa 1969, 115-117; Seibert 1976; Berthold 1984, 89-90; Wiemer 2000, 98-100.

67 Antigonus' wife was Phila, Antiochus II's sister and Seleucos I and Stratonice's daughter, with Stratonice being Antigonus Gonatas' sister. Stratonice made sacrifices in the temples of Apollo on Delos and at Delphi, which could point to her being a channel of communication between her son and brother, cf. Grainger $2010,126$. 
our sources being carried out from the sea. ${ }^{68}$ It is clear that Ptolemy attempted to move the war theater to northern Syria and sent his fleet to Cilicia; Ptolemy's ships left the Aegean and presumably operated in waters around Cyprus, which in turn must have prompted an equal countermovement of the Seleucid forces. Ptolemy's absence in the Aegean induced Antigonus and the Rhodians to attack Ptolemaic possessions in other regions of the eastern Aegean. ${ }^{69}$

Patroclus' defeat in the battle of Kos seriously damaged - but did not destroy - the Lagids' position at sea. ${ }^{70}$ No information survives about the Ptolemaic navy in that period, but it could not have succeeded against the Seleucid pressure. Year 255 saw peace return to the Aegean, but by that time Ptolemy had by all probability lost his protectorate over the League of the Islanders, without which he could not effectively control the Aegean. ${ }^{71}$ Another blow came when Antigonus seized the island of Andros towards the end of the 250s. ${ }^{72}$ Nevertheless, a string of defeats (at Kos and losses to the Seleucids in Asia Minor) did not spell the end of the Lagids' naval power in the Aegean. Neither Rhodes not Macedonia could effectively control the Cyclades in the $250 \mathrm{~s},{ }^{73}$ whereas some sources confirm that Philadelphus had regained some of his footholds in the Aegean by the end of his reign. ${ }^{74}$ Ptolemy II's successes came from his elastic and diversified foreign policy, realized through diplomacy, propaganda, strategically chosen and publicized acts of euergetism, and popularization of his dynastic cult: in the Aegean, he spread the cult of Arsinoe as the patroness of sailors. ${ }^{75}$ His coherent policy allowed him to befriend numerous Greek states and use their resources against his enemies. The Ptolemaic navy, one of the most important instrument of his policy, enabled him to pursue his ambitious foreign policy. The brief period of absolute Ptolemaic thalassocracy ended, however, after the Chremonidean War, with subsequent victories interspersed with defeats, such as one at Andros ca. 245, under the rule of Ptolemy III. ${ }^{76}$ The Ptolemaic naval dominion

${ }_{68}$ As was the case of Kelenderis in Cilicia, cf. Grainger 2010, 122-124.

69 Cf. Grainger 2010, 124-125. We have very little information about both sides' activities in Syria. It seems that Antiochus focused his attention on removing the Ptolemaic influence from Asia Minor, but there are strong indications of Philadelphus' activity, preparations for an attack in 258, and an attack in the following year, see Winnicki 1989, 58-77; Winnicki 1991, 87-104; Huss 2001, 284-285.

${ }_{70}$ Plut. Mor. 181c (Apophthegm. Reg. 30.2); Athen. 5.209e. Sources mention 'Ptolemy's generals.' One of them was certainly Patroclus; we do not know the identity of the other one.

${ }^{71} I G$ XI 2.116. The text of the inscription does not necessarily indicate that Ptolemy II and Antigonus Gonatas signed a formal peace treaty. From that time onwards, the League of the Islanders no longer appears in source documents, cf. Hammond - Walbank 1988, 292.

72 Plut. Arat. 12.2.

73 Cf. Hammond - Walbank 1988, 294; Reger 1992, 34-35, 41-43. Antigonus' situation at sea was complicated by the rebellion of his nephew, Alexander, and the consequent loss of important naval bases in Corinth and Chalcis on Euboea for a few years (ca. 251-245).

74 IG XI 4.1038; 1043. Cf. Bruneau 1970, 519-525, 531-533; Buraselis 1982, 170-172; Hölbl 2001, 45 contra Hammond - Walbank 1988, 295. For Keos, see Cherry - Davis 1991, 14-17.

75 Cf. Marquille 2008, 49-61; Müller 2009, 156-299, 353-379; Grabowski 2014.

76 Spectacular successes of the Ptolemaic fleet during that period cannot be ruled out, but they are unlikely. Some historians (e.g. Hölbl 2001, 45; Marquaillae 2008, 48, note 43 and, with more caution, Buraselis 1982, 170) believe that in ca. 250 Ptolemy II defeated the Macedonian fleet. However, accounts about this event (Ps. Aristeas 180; Josephus, $A J$ 12.93) are uncertain. The authors mention Philadelphus' great success over Gonatas, whose anniversary was reportedly celebrated in Alexandria. Tarn $(1913,131$, note 43$)$ rightly observed that the information from these accounts should rather be associated with an episode from the beginning of 
in the Aegean, it appears, happened due to a felicitous turn of circumstances that allowed Philadelphus to control a number of factions and establish a number of bases he would not or could not have controlled at any other point before or after the Chremonidean War.

\section{AbBreviations}

I. Cret. $\quad-\quad$ M. Guarducci, Inscriptiones Creticae, 4 vols., Roma 1935-1950.

I. Labraunda - J. Crampa (ed.), Labraunda: Swedish Excavations and Researches, vol. III, part 1-2: Greek Inscriptions, Lund 1969-1972.

I. Milet $\quad-\quad$ C. Fredrich et al., Inschriften von Milet, 2 vols. in 10 parts, Berlin 1906-1935.

RC - C. B. Welles, Royal Correspondence in the Hellenistic Period: A Study in Greek Epigraphy, New Haven, Conn. 1934 (reprint Chicago 1974).

StV - H. H. Schmitt, Die Staatsverträge des Altertums, Vol. III: Die Verträge der griechisch-römischen Welt von 338 bis 200 v. Chr., München 1969.

\section{BIBLIOGRAPHY}

Bagnall, R. S. (1976), The Administration of Ptolemaic Possessions Outside Egypt, Leiden.

Beloch, K. J. (1927), Griechische Geschichte, Bd. IV.2, Berlin-Leipzig.

Berthold, R. M. (1984), Rhodes in the Hellenistic Age, Ithaca-London.

Bevan, E. (1927), The House of Ptolemy, London.

Bikerman, E. (1938), Sur les batailles navales de Cos et d'Andros, REA 40: 369-383.

Bouché-Leclerq, A. (1903-1907), Histoire des Lagides, vols. I-IV, Paris.

Brulé, P. (1978), La piraterie crétoise hellénistique, Paris.

Brun, P. (1991), Les Lagides à Lesbos: Essai de chronologie, ZPE 85: 99-113.

Bruneau, P. (1970), Recherches sur les cultes de Déelos à l'époque hellenistique et à l'époque impériale, Paris.

Buraselis, K. (1982), Das hellenistische Makedonien und die Ägäis. Forschungen zur Politik des Kassandros und der drei ersten Antigoniden (Antigonas Monophthalmos, Demetrios Poliorketes und Antigonas Gonatos) im Ägäischen Meer und in Westkleinasien, München.

Burstein, S. M. (1982), Arsinoe II Philadelphos: A Revisionist View, in: W. L. Adams, E. N. Borza (eds.), Philip II, Alexander the Great and the Macedonian Heritage, Washington: 197-212.

Caneva, S. G. (2013), Arsinoe divinizzata al fianco del re vivente Tolemeo II. Uno studio di propaganda greco-egiziana, Historia 62: 280-322.

Ptolemy II's reign. On the other hand, it is difficult to agree with his categorical opinion that these sources refer, in a distorted way, to Ptolemy Keraunos' victory over Antigonus. At the same time, we cannot rule out that the sources, despite their inaccuracies, recorded true information about Philadelphus' successes. One of the letters of Apollonius the dioiketes from early 250 is about cutting down trees for ship-building, which might be related to the possible activity of the Egyptian fleet, cf. Fraser - Roberts 1949. 
Cardinali, G. (1904), Creta e le grandi potenze ellenistiche sino alla guerra di litto, Rivista di Storia Antica 9: 69-94.

Carney, E. D. (2013), Arsinoë of Egypt and Macedon: A Royal Life, Oxford.

Casson, L. (1971), Ships and Seamanship in the Ancient World, Princeton, New Jersey.

Cherry, J. F., Davis, J. L. (1991), The Ptolemaic Base at Koressos on Keos, BSA 86: 9-28.

Cherry, J. F., Davis, J. L., Matzourani, E. (eds.) (1991), Landscape Archaeology as Long-Term History: Northern Keos in the Cycladic Islands from Earliest Settlement until Modern Times, Los Angeles.

Cohen, G. M. (1995), Hellenistic Settlements in Europe, the Islands and Asia Minor, Berkeley-Los Angeles.

Coşkun, A. (2016), Ptolemaioi as Commanders in 3rd-Century Asia Minor and Some Glimpses on Ephesos and Mylasa during the Second and Third Syrian Wars, in: B. Burak Takmer, E. N. Akdoğu Arca, N. Gökalp Özdil (eds.), Vir doctus anatolicus: Studies in Memory of Sencer Şahin, Istanbul: 257-279.

Crampa, J. (1969), Labraunda: Swedish Excavations and Researches, vol. III: The Greek Inscriptions, part I: 1-12 (Period of Olympichus), Lund.

Dack, E. van't, Hauben, H. (1978), L'apport égyptien à l'armée navale lagide, in: H. Maehler, V. M. Strocka (eds.), Das ptolemäische Ägypten. Akten des internationalen Symposions 27.-29. September 1976 in Berlin, Mainz: 59-94.

Dack, E. van't (1988), Les commandants de place Lagides á Théra, in: E. van’t Dack, Ptolemaica Selecta. Études sur l'armée et l'administration lagides, Leuven: 124-145.

Dmitriev, S. (2011), The Greek Slogan of Freedom and Early Roman Politics in Greece, Oxford.

Domingo Gygax, M. (2000), Ptolemaios, Bruder des Königs Ptolemaios III. Euergetes, und Mylasa. Bemerkungen zu I. Labraunda Nr. 3, Chiron 30: 353-366.

Domingo Gygax, M. (2002), Zum Mitregentem des Ptolemaios II Philadelphos, Historia 51: 49-56.

Dreyer, B. (1999), Untersuchungen zur Geschichte spätklassischen Athen (322-ca. 230 v. Chr.), Stuttgart.

Errington, R. M. (2008), A History of the Hellenistic World: 323-30 BC, Cambridge.

Fraser, P. M. (1972), Ptolemaic Alexandria, vols. I-III, Oxford.

Fraser, P. M., Roberts, C. H. (1949), A New Letter from Apollonius, CE 48: 289-294.

Gabbert, J. J. (1983), Grand Strategy of Antiochus Gonatas and the Chremonidean War, Ancient World 8: $129-136$.

Garland, R. (1987), The Piraeus: From the Fifth to the First Century BC, London.

Gill, D., Foxhall, L., Bowden, H. (1997), Classical and Hellenistic Methana, in: C. Mee, H. Forbes (eds.), A Rough and Rocky Place: The Landscape and Settlement History of the Methana Peninsula, Greece, Liverpool: 62-76.

Grabowski, T. (2008), Ptolemy's Military and Political Operations in Greece in 314-308 BC, Electrum 14: 33-46.

Grabowski, T. (2010), Związek Etolski w polityce greckiej pierwszych Ptolemeuszy, in: E. Dąbrowa et al. (eds.), Hortus Historiae. Księga pamiatkowa ku czci Profesora Józefa Wolskiego w setna rocznice urodzin, Kraków: 191-218.

Grabowski, T. (2014), The Cult of Arsinoe II in the Foreign Policy of the Ptolemies, in: M. Salamon (ed.), Within the Circle of Ancient Ideas and Virtues: Studies in Honour of Professor Maria Dzielska, Kraków: 117-128.

Grainger, J. D. (2010), The Syrian Wars, Leiden.

Groot, A. W. de (1917/1918), Ptolemaios der Sohn, RhM 72: 446-463.

Habicht, C. (1956), Gottmenschentum und griechische Städte, München.

Habicht, C. (1979), Untersuchungen zur politischen Geschichte Athens im 3. Jahrhundert v. Chr., München.

Habicht, C. (1997), Athens from Alexander to Anthony, Cambridge, Mass.

Hallof, K., Mileta, C. (1997), Samos und Ptolemaios III. Ein neues Fragment zu dem samischen Volksbeschluss AM 72, 1957, 226 Nr. 59, Chiron 27: 256-283. 
Hammond, N. G. L., Walbank, F. W. (1988), A History of Macedonia, vol. 3: 337-167 B. C., Oxford.

Hauben, H. (1970), Callicrates of Samos: A Contribution to the Study of the Ptolemaic Admiralty, Leuven.

Hauben, H. (1983), Arsinoé II et la politique extérieure de l'Égypte, in: E. van’t Dack, P. van Dessel, W. van Gucht (eds.), Egypt and the Hellenistic World: Proceedings of the International Colloquium Leuven 24-26 May 1982, Leuven: 99-127.

Hauben, H. (1987), Cyprus and the Ptolemaic Navy, RDAC: 213-226.

Hauben, H. (2013), Callicrates of Samos and Patroclus of Macedon, Champions of Ptolemaic Thalassocracy, in: K. Buraselis, M. Stefanou, D. J. Thompson (eds.), The Ptolemies, the Sea and the Nile: Studies in Waterborne Power, Cambridge: 39-65.

Hauben, H. (2014), Ptolemy's Grand Tour, in: H. Hauben, A. Meuss (eds.), The Age of the Successors and the Creation of the Hellenistic Kingdoms (323-276 B. C.), Leuven: 235-262.

Heinen, H. (1972), Untersuchungen zur hellenistischen Geschichte des 3. Jahrhunderts v. Chr. Zur Geschichte der Zeit des Ptolemaios Keraunos und zum Chremonideischen Krieg, Wiesbaden.

Herbst, R. (1937), Pelopsinselchen, RE XIX, 1: 392-393.

Hölbl, G. (2001), A History of the Ptolemaic Empire, London.

Hunter, R. (2003), Theocritus: Encomium of Ptolemy Philadelphus, Text and Translation with Introduction and Commentary, Berkeley-Los Angeles.

Huss, W. (1998), Ptolemaios der Sohn, ZPE 121: 229-250.

Huss, W. (2001), Ägypten in hellenistischer Zeit 332-30 v. Chr., München.

Huss, W. (2011), Die Verwaltung des Ptolemaiischen Reichs, München.

Kralli, I. (2017), The Hellenistic Peloponnese: Interstate Relations; A Narrative and Analytic History, from the Fourth Century to 146 BC, Swansea.

Kreuter, S. (1992), Aussenbeziehungen kretischer Gemeinden zu den hellenistischen Staaten im 3. und 2. Jh. v. Chr., München.

Labarre, G. (1996), Les cités de Lesbos aux époques hellénistique et impériale, Lyon.

Launey, M. (1945), L'exécution de Sotades et l'expedition de Patroklos dans la Mer Egée (266 av. J.-C.), REA 47: 33-45.

Launey, M. (1949-1950), Recherches sur les armées hellénistiques, vols. I-II, Paris.

Lauter-Bufe, H. (1989), Die Festung auf Koroni und die Bucht von Porto Raphti, ein Beitrag zur Geschichte Athens im 3. Jh. v. Chr., in: H. Lauter, H. Lauter-Bufe, H. Lohmann (eds.), Attische Festungen, Beiträge zum Festungswesen und zur Siedlungsstruktur vom 5. bis zum 3. Jh. v. Chr., Marburg: 67-102.

Longega, G. (1968), Arsinoe II, Roma.

Łoposzko, T. (1994), Starożytni piraci Morza Śródziemnego, Lublin.

Macurdy, G. (1932), Hellenistic Queens: A Study in Woman-Power in Macedon, Seleucid Syria and Ptolemaic Egypt, Baltimore.

Marek, C. (1984), Die Proxenie, Frankfurt am Main, Bern-New York.

Marquaille, C. (2008), The Foreign Policy of Ptolemy II, in: P. McKechnie, P. Guillaume (eds.), Ptolemy II Philadelphus and His World, Leiden: 39-64.

McCredie, J. R. (1966), Fortified Military Camps in Attica, Princeton, New Jersey.

Meadows, A. (2006), The Ptolemaic Annexation of Lycia, SEG 27.929, in: K. Dörtlük et al. (eds.), The IIIrd Symposium of Lycia. 07-10 November 2005, Antalya. Symposium Proceedings, vol. 2, Antalya: 459-470.

Meadows, A. (2012), Deditio in Fidem: The Ptolemaic Conquest of Asia Minor, in: C. Smith, L. M. Yarrow (eds.), Imperialism, Cultural Politics, and Polybius (Papers in Memory of Peter Derow), Oxford: $113-133$.

Meuss, A. (2013), The Territorial Ambitions of Ptolemy I, in: H. Hauben, A. Meuss (eds.), The Age of the Successors and the Creation of the Hellenistic Kingdoms (323-276 B. C.), Leuven: 263-306.

Meyer, E. (1935), Methana, RE XV, 2: 1375-1379. 
Mueller, K. (2006), Settlements of the Ptolemies: City Foundations and New Settlement in the Hellenistic World, Leuven.

Müller, S. (2009), Das hellenistische Königspaar in der medialen Repräsentation, Berlin.

Murray, W. M. (2012), The Age of Titans: The Rise and Fall of the Great Hellenistic Navies, Oxford.

Olck, F. (1909), Feige, RE VI, 2: 2100-2151.

O'Neil, J. L. (2008), A Re-Examination of the Chremonidean War, in: P. McKechnie, P. Guillaume (eds.), Ptolemy II Philadelphus and His World, Leiden: 65-89.

Oliver, G. J. (2001), Regions and Micro-regions: Grain for Rhamnous, in: Z. H. Archibald et al. (eds.), Hellenistic Economies, London-New York: 137-155.

Ormerod, H. A. (1924), Piracy in the Ancient World, Liverpool.

Orth, W. (1977), Königlicher Machtanspruch und städtische Freiheit. Untersuchungen zu den politischen Beziehungen zwischen den ersten Seleukidenherrschern (Seleukos I, Antiochos I, Antiochos II) und den Städten des westlichen Kleinasiens, München.

Paschidis, P. (2008), Between City and King: Prosopographical Studies on the Intermediaries between the Cities of the Greek Mainland and the Aegean and the Royal Courts in the Hellenistic Period, 322-190 BC, Athens.

Peremans, W. (1939), La date de la bataille navale de Cos, $A C$ 8: 401-408.

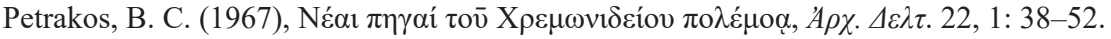

Piejko, F. (1991), Decree of the Ionian League in Honor of Antiochus I, ca 267-262 B. C., Phoenix 45: 126-147.

Reger, G. (1985), The Date of the Battle of Kos, AJAH 10: 155-177.

Reger, G. (1994), The Political History of Kyklades 260-200 B. C., Historia 43: 3-69.

Rice, E. E. (1983), The Grand Procession of Ptolemy Philadelphos, Oxford.

Robert, L. (1960), Sur un décret des Korésiens au musée de Smyrne, Hellenica 11-12: 132-176.

Robert, L. (1968), Bulletin épigraphique, REG 81: 420-549.

Rodriguez, P. (2000), L'intervention ptolémaïque dans la guerre de Chrémonidès au vu du monnayage lagide, $R N$ 155: 17-34.

Rostovtzeff, M. (1941), The Social and Economic History of the Hellenistic World, vols. I-III, Oxford.

Seibert, J. (1971), Ptolemaios I und Milet, Chiron 1: 159-166.

Seibert, J. (1976), Die Schlacht bei Ephesos, Historia 25: 45-61.

Souza, P. de (1999), Piracy in the Graeco-Roman World, Cambridge.

Spyridakis, S. V. (1970), Ptolemaic Itanos and Hellenistic Crete, Berkeley.

Tarn, W. W. (1909), The Battles of Andros and Cos, JHS 29: 264-285.

Tarn, W. W. (1913), Antigonos Gonatas, Oxford.

Tracy, S. V. (1990), Hands in Samian Inscriptions of the Hellenistic Period, Chiron 20: 59-96.

Tunny, J. A. (2000), Ptolemy "the Son" Reconsidered: Are There Too Many Ptolemies?, ZPE 131: 83-92.

Vanderpool, E., McCredie, J. R., Steinberg, A. (1962), Koroni: A Ptolemaic Camp on the East Coast of Attica, Hesperia 31: 26-62.

Vanderpool, E., McCredie, J. R., Steinberg, A. (1964), Koroni: The Date of the Camp and the Pottery, Hesperia 33: 69-75.

Welles, C. B. (1934), Royal Correspondence in the Hellenistic Period: Study in Greek Epigraphy, New Haven.

Wiemer, H. U. (2000), Krieg, Handel und Piraterie. Untersuchungen zur Geschichte des hellenistischen Rhodos, Berlin.

Will, E. (1979), Histoire politique du monde hellénistique (323-30 av. J.-C.), t. I, Nancy.

Winnicki, J. K. (1989), Operacje wojskowe Ptolemeuszów w Syrii, Warszawa.

Winnicki, J. K. (1991), Der zweite syrische Krieg im Lichte des demotischen Karnak-Ostrakons und der griechischen Papyri des Zenon-Archivs, JJP 21: 87-104. 